\title{
THE DYNAMICS OF GERMAN CARTELS AND PATENTS. I*
}

\author{
HEINRICH KRONSTEIN†
}

$\mathrm{I}$

N TWO articles, of which this is the first, I shall discuss the development of cartels in Germany and their relation to patents. The following questions will receive primary consideration:

I. Why did Germany become the homeland of the cartels and the principal exporter of technology?

2. What has been accomplished by and with the cartels in the different stages of development?

3. What was the significance of patents in the development of the cartel device?

4. What was the effect of these cartels on the state and society in the several stages of development?

5. How did the German government react to the development of cartels and the use of the patent device in the several stages of development?

6. What was the reaction of other countries to the German cartel and patent system?

7. How did Hitler utilize the cartel and patent system for the purpose of preparing for and waging the war?

8. How did he use especially the obligations assumed by firms outside of Germany, to German firms, for his purpose?

$I$ am not going to answer all these questions, but $I$ hope to contribute something to the understanding of the phenomenon under discussion.

\section{DEVELOPMENT BEFORE HITLER}

Cartels and other forms of monopoly power may be considered from the point of view of their legal aspects (internal organization and relations to actual or prospective contractees and governmental authorities) or from the point of view of their economic aspects (effect on prices, wages and

* This article was the basis of the writer's testimony before the Senate Patent Committee. The views expressed are the views of the writer only and not those of the Department of Justice.

$\dagger$ Adviser in foreign law and property, Department of Justice, Anti-Trust Division; Professor of Comparative Law, Georgetown University Law School; formerly practicing attorney in Mannheim, Germany, specializing in cartel and monopoly law.

$\ddagger$ A second article by Mr. Kronstein dealing with the developments after Hitler will appear in a later issue of the Review. 
salaries, production, and distribution of markets). ${ }^{x}$ All these aspects have been analyzed again and again. ${ }^{2}$ The analyses have one thing in common: they deal with a general type of "cartel and monopoly power." Their aim is to justify a judgment taken to be correct with regard to the entire subject matter. In contrast this article deals only with the dynamics of the German cartels and other forms of monopoly power especially in the light of their repercussions on the outside world. Such a study is worthwhile only if free from the dogmatic method so often used in discussions of this problem by people believing in free trade as the only form of sound commerce or by people convinced of the justification of a hostile attitude against capitalist leaders. None of these groups even tries to understand the facts. The less prejudiced our study, the more forceful can its conclusions be.

Cartels are tools used to accomplish certain aims. They have no lives of their own. The people behind them give them life. The psychology of these people, their efficiency or laziness, their defensive or offensive spirit, make up the spirit of the cartels. The specific intent of the people involved, however, is of no significance. An agreement between two local banks to exchange a list of debtors, or to make identical conditions on loans, has in itself no monopolistic end. The banks want to prevent losses in case of insolvency of a mutual customer and to have the benefit of the best protection lawyers can furnish. When in the regular course of business no bank is open to this customer, then the agreement between the two local banks becomes, from his point of view and therefore from the public point of view, a monopolistic agreement. The public has an interest in a merchant who may tomorrow be at the mercy of the bureaucracy of a single bank organization. ${ }^{3}$ This instance shows how a cartel agreement of the most simple form may develop into a cartel agreement influencing the public welfare. The general trend and the aims of the cartel are the only things which count.

\footnotetext{
× Rudolf Callman defined a cartel as "a contractual association of legally independent entrepreneurs in the same or a similar field of business, formed with the intent, effect, or potentiality of influencing the market by means of regulation of competition." Investigation of Concentration of Economic Power, Hearings before the Temporary National Economic Committee, 75th Cong. 3 d Sess., at 13,347 (I940).

'See Wolfers, Kartell Problem im Lichte der deutschen Kartelliteratur (I93I) for a bibliography of cartel literature.

3 It is interesting to note that the representative of the German banks made the point that the government can have no interest in any cartel of banks providing uniform conditions of credit "since they do not contain any legal binding of the outsiders and have no intention of governing the market." Ausschuss zur Untersuchung der Erzeugungs- und Absatzbedingungen der deutschen Wirtschaft. Verhandlungen und Berichte. 3. Arbeitsgruppe. Wandlungen in den Rechtsformen der wirtschaftlichen Organisationsformen, t. 4. Kartellpolitik 2 I6 (I930).
} 
In Germany, since I879, cartels have been used for three purposes: I) to satisfy the profit hunger of private business organizations; 2) at the same time to win influence over the political and economic organization of the nation on behalf of private interests; 3 ) to serve as a means of governmental and political power. There is no legal or economic form of a cartel which would be wholly unfit to serve any of these three aims. A cartel regulating prices or conditions of delivery may be a powerful means of influencing, or even making ineffective, the tariff policy of a government. On the other hand, a complicated cartel with a joint sales agency, patent exchange, and the like, may prove to be merely a means of obtaining additional profits. Therefore, a student of the dynamics of the German cartel system would not accomplish much by describing the several forms of cartels. ${ }^{4}$ He would find that the economic history of all countries in all times contains many agreements between business organizations concerning prices, working conditions, and the distribution of markets. For the entire economic machinery such agreements become significant only when they determine, in connection with other factors, in any way the economic and political structure of a country.

The German cartel system developed under very specific conditions to accomplish very specific ends. Germany was the last western power to enter the industrial field. Until the legislation of the Zollverein made possible a sufficiently high tariff to permit the establishment of production plants, it was almost exclusively the customer for products manufactured by other nations. Friedrich List, who studied economics in the United States as well as Germany, came to the conclusion that in both countries any industrial development was impossible so long as domestic industry was not given a chance to develop under what he called "an educational tariff."s Although German trade and industry began to develop under the protection of the Zollverein, the real significance of the teaching of List did not obtain great influence until much later. Most "economists" were opposed to Bismarck's tariff bill in 1879 . They called such legislation a gift to the farmers and a deadly blow to the slowly developing German industry. They were in the good company of the United States Chargé

4 Handler, A Study of the Construction and Enforcement of the Federal Antitrust Laws, TNEC Monograph No. 58, at 922 (194I).

5 The basic statement of his conclusions is that, "History teaches us how nations by nature gifted with all means necessary to conquer wealth and power, may repeatedly change their economic system to meet the demands of each stage of their development. They can overcome the state of barbarism by free trade with more progressive nations. After some time they may, by trade limitations, develop plants, fisheries, shipping and foreign trade, and finally, in the highest stage, they may slowly return to the principles of free trade to protect their farmers, manufacturers and merchants against laziness, and to induce them to maintain the acquired superiority." List, Das nationale System der politischen Oekonomie I79 (I84I). 
d'Affaires in Berlin, who wrote to the State Department reporting the enactment of the Bismarck tariff statute on February I5, I879:

The law levying restrictive duties on imported products meets with great opposition, and its injurious effect in a country which, like Germany, is able to produce so little of its own food, and is dependent on others for the raw materials of its manufacturers, would seem to be self-evident. It is in reality a desperate attempt to resist the competition of cheap produce and manufactures of the United States and Great Britain, and to make up in a false way for the great loss of capital and labor in Germany resulting from the heavy drain on the muscular and mental resources of the nation caused by a huge standing army, and the doubt and loss occasioned in business by consistent Continental wars and rumors of war. As the reports of our consuls here show, much of the working capital of Germany is idle.....6

On August 15, I879, we find furthermore in one of the first reports of the new Ambassador, Mr. White, to the Secretary of State the following statement:

There are some who see in the new protective tariffs nothing but a necessary step to a reorganization of German industry. The idea appears to be that this industry shall exist for Germany alone; that the government shall protect it from foreign competitors, while it clothes itself in some new form of guilds, with the object, of course, of improving the condition of both operatives and employers. This policy of isolation as regards Prussia has increased since the military successes of 1870 , and it is further strengthened by the necessity the German Government considers itself under of maintaining a huge standing army.

Mr. White realized the significance of the new "guilds," but he misunderstood their policy in viewing it as a policy of isolationism. It was just the opposite. ${ }^{7}$

The exports of Germany increased as never before. After this date, in almost every field German industry developed into the most powerful in Europe, whereas in 1876 the German Commissioner of the Philadelphia World Exposition called the German goods "an exhibition of cheap and bad products." only in the European countries outside of Germany, but in all parts of the world. Shipments of hard coal from Germany are an example of the growth of her exports for this period. From I886 to I 905 the annual tonnage more than doubled.

' Papers Relating to the Foreign Relations of the United States, Transmitted to Congress, with the Annual Message of the President, December I, I879, at 360-6I (I879).

7 Ibid., at 397 . The only man who realized what the future would bring was the leader of the free trade group, Ludwig Bamberger, who stated, "The consequences of high tariffs will be the resurrection of conditions sometimes called 'the union of industrialists.' The German sheet metal manufacturers - there are only six-are so sure of themselves that they already are building its union." Protokolle des Deutschen Reichstag. 4. Periode. 2 Session (1879).

${ }^{8}$ Statement of the German Commissioner at the Exhibition Reuleaux. 
This development, which was actually contrary to all the theories of classical economists, was only possible because of the cartel device used in combination with high tariff legislation. ${ }^{9}$ For instance, the mines entrusted the sale of all their coal to the Rheinisches Westfaelisches Kohlensyndikat, ${ }^{\text {xo }}$ a corporation whose shares were owned exclusively by the cartel members. No sales to anyone else were permitted. The syndicate became the only buyer of the mined products and the only seller to the public. It paid to the member firms the same price, no matter to whom the product was sold. Coal which sold domestically in Bavaria for 17 RM was sold abroad in Austria for $8 \mathrm{RM}$. This was a typical case of the dumping practices followed by cartels.

Four hundred fifty cartels of similar structure existed in Igor. ${ }^{\mathrm{Ix}}$ The most important instances can be found in the coal, iron, electrical, chemical, textile, rubber, timber, paper, glass, and building industries. Ways and means to regulate the export business and to distribute the profits in the domestic field and the losses in the foreign field were accomplished in different ways. For example, the Oberschlesische Roheisensyndikat in Zabrze provided for the establishment of a joint sales agency, which should not sell in its own name but rather as agent of each of the member firms. At the end of six months prices were to be equalized with the result that each member firm received the same proceeds for the iron delivered.

The Stahlwerksverband A. G. Düsseldorf compelled all owners of steel mills to sell all their products to it. The price obtained by the Verband on selling the product was the basis of accounting with each member. The contract contains the provision: "An exporting plant shall have no better but also no worse position than it would have if all member firms had sold in the domestic and foreign markets what would be their theoretical quotas." 12

In I880 the Badische Anilin und Soda Fabriken, Ludwigshafen, opened its laboratory to engage in the research of industrial methods for manufacturing indigo dyestuffs. "Seventeen years of uninterrupted work was not too long to accomplish this end. In 1897 the first success was accomplished." ${ }^{3}$ In 1888 the Elberfelder Farbenfabriken (Bayer) began the

9 Von Beckerath, Der moderne Industrialismus ${ }_{367}$ (1935).

${ }^{10}$ The exceptions to this rule were in themselves quite important, but they should not be discussed here because they did not change the general aspect. Cf. Fletchtheim, Die rechtliche Structur der Kartelle (IgIO).

" Kartell Engnete I. I. Teil, at 2 (I902). 12 Ibid., at 273.

${ }^{23}$ Duisberg, Verwaltungsbericht des deutschen Museums 40-4I (I9IO-II). Since Duisberg was one of the founders of the German chemical industry and is considered its most representative speaker his works are a valuable source of material. 
production of pharmaceuticals. ${ }^{14}$ Dyestuffs and pharmaceuticals proved to be the basis of the development of the chemical industry.

Foreign inventions were brought to Germany, improved, and used to a certain extent, as the basis of German exports. In 1882 the Continental Edison Company of Paris granted Emil Rathenau a license to use its basic bulb patents, which became the basis of the establishment of the A.E.G. ${ }^{\text {Is }}$ In I905 the British Marconi Company assigned the rights under the Marconi patents to Telefunken. ${ }^{16}$ The opportunity given to German chemists to organize research made it possible to overcome the lack of raw material in Germany, at least to a certain extent, and for a limited period of time these research laboratories in Germany, made possible by high tariffs and the cartel system, became the most precious raw material Germany had. In I904 Carl Duisberg made the following statement to American chemists:

.... I must now express my satisfaction with the German chemist and the German chemical industry. In this field lies the strength of Germany, a consequence perhaps of the peculiarity of the German character. Forced by want of natural resources and unprovided with American abundance, the German in scientific exploration must proceed in a cautious and economical manner, always bent on patient and minute research.....

Notwithstanding all [the technological advances of American industry] I think that we Germans need not be alarmed in the near future. The time for the development of the organic chemical industries on a large scale has not yet arrived. As I have shown before, the Germans are masters in manufacture where numberless products are employed in a series of reactions which finally lead to the finished product, and require manual labor, which cannot possibly be replaced by machinery, while Americans may claim to be masters where manufacture on a large scale is concerned, which can be done by machinery. Yet we must not leave out of consideration the very important facts that in America wages are extraordinarily high, that the conditions of life are here much more elaborate, and last, but not least, that the employees, and more particularly the workmen, manifest a spirit of independence, which has become especially noticeable during the last few years. By their labor unions the workmen attempt not only to raise wages to a height which will make manufacturing difficult and less profitable, but they are also endeavoring to take the control of the works out of the hands of the educated managers and put it into the hands of irresponsible labor leaders. This movement, as I have above shown, is especially fatal for the chemical industry in which our ,glorious science should be supreme.

[After American natural resources are depleted] it will be found that the only way that leads to success in chemical manufactures is a combination of science and technics, the two branches of which eminent representatives are today assembled here, men who in their spheres have done so much already for the advancement of indus-

${ }_{4}$ Duisberg, Lebenserinnerungen 66 (I933).

${ }_{5}$ Meinhardt, Der Aufhau der Gluehlampenindustrie I2 (1932).

${ }^{6}$ Von Bronk, Telefunken Patents, Twenty-five Years of Telefunken (I928). 
tries. It will be found that technical progress in this industry can only be secured on the basis of purely scientific research. . . . . .77

The immediate price to be paid by Germany for this staggering development seemed not too high from the point of view of the prevailing Prussian philosophy. The freedom of action of the individual disappeared more and more. Free competition, where it existed, became a fight for quotas in the future cartel, while the liberal economists in the universities closed their eyes and pretended to live in a period of free trade. Each device for the protection of the individual became unconsciously a device for control by cartel and monopoly power. The fact that freedom of action disappeared in the sphere of life in which it was supposed to be most predominant had its effect on the entire philosophy of every man whatever his place might be in the nation.

The Patent Statute of $1877^{18}$ granted a seventeen-year monopoly to the individual applicant for the patent as consideration for allowing the invention to be available to the public, and as a reward for his individual efforts in the interest of science. Werner von Siemens, before the enactment of the first patent statute, praised the protection of the individuality of the inventor and the benefit to society from such protection. ${ }^{19}$ But no German patent statute up to $193^{66^{20}}$ mentioned the inventor at all.

In I 900 Carl Duisberg praised the provision giving competitors the right to file objections as the basis for efficient application of the patent law in the interest of the public welfare. ${ }^{2 x}$ In Igor Duisberg made the following statement:

17 Duisberg, The Influence of Liebig on the German Chemical Industry (1904). Reprinted in Duisberg, Abhandlungen, Vortraege und Reden (I923).

${ }^{88}$ Statute of July $\mathrm{I}, \mathrm{1877}$, Reichsgesetzblatt 50I.

19 Protokoll des Kongresses fuer gewerbliches Eigentum in Frankfurt-am-Main 16 ( $\mathrm{rg} 00$ ).

${ }^{20}$ Statute of May 5, x936, 2 Reichsgesetzblatt, Ir 74 et seq. The new patent statute provides that the name of the inventor shall be mentioned in the application, in the publication, and in the patent certificate itself. This protection of the "honor of the inventor" did not change the principal use made of patents to serve as a means of monopoly. It is quite typical of the propaganda of the National Socialist Party to appeal to the individualistic rights of the inventor to give him a so-called "honor"-and at the same time not only to sustain monopoly powers of the entrepreneurs but to strengthen it to the extreme. The same thing happened in regard to the so-called destruction of the "Anonyme" business economy by corporations, promised by the Nazis, announced in a number of statutes-with the effect that today corporations and monopoly powers are stronger than ever before.

2I Protokoll des Kongresses fuer gewerbliches Eigentum in Frankfurt-am-Main $\mathrm{r}_{4}$ (1900). He blamed the machine tool industry for not filing objections against patent applications often enough. Such protest alone "gives the Patent Office a chance of a reasonable examination. The idea cannot be patented, even if it is worth a million. Only if the idea becomes an actual invention can a patent be asked for. If you are too lenient you do not help the inventor but you do harm to the industry." 
The percentage of granted patents, which amounted to 36 per cent in I889, rose to $5 \circ$ per cent in 1899 and to $6 \mathrm{I}$ per cent in 1900 . I believe if they continue in I $90 \mathrm{O}$ the percentage of granted patents will amount to 70 or 80 , or even Ioo per cent. It is just horrible. Such a large number of doubtful and bad patents has been granted that many suits in our courts will follow. Furthermore, the Patent Office induced by the rather dark language of the amendment of the patent law and by the decisions of the Reichsgericht, adopted the practice of no longer setting forth the connections between the patent and another patent. ....22

In Ig०2 Duisberg had this to say:

You citizens in practical life will understand that you cannot define an invention by just counting your fingers. Processes for the common good . . . . shall not be closed to the industry by granting patents. Some of these processes are not more than a change of temperature or distillation of the product in vacuum, or of similar kind. That is done continually - the statistics of the Patent Office show that the number of objections against patents increased very much, especially in the chemical industry.23

\section{A few years later Duisberg observed a complete shift:}

In Class I2 [one of two classes of chemical patents] I860 patent applications have been filed and only II were contested. In Class 22 [the other class of chemical patents] II49 patent applications have been filed and only 5 have been contested. The reason is not that the chemical industry did not like to begin patent litigation but the chemical industry is tired. It does not care to be continually misunderstood any longer. It does not like to wait for years until it can have a decision of the Reichsgericht. ${ }^{24}$

Did Duisberg really believe what he said here, that the lack of understanding by the Patent Office, especially on the part of lawyers who were very much disliked by Duisberg, was the reason for the decrease of patent litigation? Did he forget that he himself began the elimination of patent litigation between the dyestuff manufacturers by making a "peace treaty" in the entire field of dyestuffs with AGFA in $1889^{25}$ and with other dyestuff firms in 1904 ? There no longer was any need for patent litigation in the dyestuff field.

22 Protokoll des Kongresses fuer gewerbliches Eigentum in Köln 33 et seq. (Igor).

${ }^{23}$ Protokoll des Kongresses fuer gewerbliches Eigentum in Düsseldorf in I902, Zeitschrift fuer Angewandte Chemie 980 et seq. (1908).

24 Protokoll des Kongresses fuer gewerbliches Eigentum in Leipzig 75 et seq. (rgo8). The same development with regard to patent litigation, which is in the opinion of Duisberg the basis of patent protection in the interest of the common welfare, can be seen in the electrical industry. It its tremendous struggle as the owner of most European patent rights for use of wolfram wire, the A.E.G. was supported by Siemens \& Halske and General Electric. In the beginning more than thirty objectors against the patents appeared. It was one of the biggest patent fights since the patent statute was enacted. The fight went through the channels of the Patent Office and of the regular courts until the patent was finally granted. In the end an agreement was reached between all firms manufacturing bulbs to protect each other's patents, to exchange information and patents, and to stop the fight. Meinhardt, Entwicklung und Aufbau der Gluehlampenindustrie 43 (1932).

${ }_{25}$ Duisberg, Lebenserinnerungen 48 (I933). 
Exactly the same development can be seen in the pharmaceutical industry, again under Duisberg's strong influence. In his very remarkable memorandum concerning the merger of the German dyestuff firms, submitted to all members of the boards of these concerns in I9O4, he already mentioned the existence of certain agreements, and complained bitterly about attacks against the possibility of protecting by patents the manufacture of pharmaceutical products. "Who knows how long it will be until the legislators in Germany, Austria, England and America will adopt the opinions already existing in the Latin countries to deny patent protection to pharmaceutical products and to processes for the manufacture of such products. The same opinion can be found in the trademark field. Influential groups try to abolish the possibilities of protecting trademarks for pharmaceutical products." Duisberg was very well aware of the tremendous power which this absolute security of big industry as patent owners amounted to, not only in the domestic market, where competition was absolutely excluded, but also in the foreign market, and not only for the period of the patent's existence, but afterwards. In his memorandum of I904 he stated proudly that there was no one who would dare to offer any competition against the power of the combined firms. In a speech in London, he stated:

But you will see when the problems have been solved and when the patents have run out and the manufacture is free to every one, why shouldn't the English and foreign firms decide to cope with the German firms and compete with them again? In my opinion this would be futile and would be of no avail. Even in Germany where, as we have seen, the conditions are the most favorable, it would now be scarcely possible, or at least be a singular coincidence, if the manufacturer, although possessed of energy and capital, should succeed in building up a new firm in the color line so as to successfully compete against the existing powerful works, and this applies even more to other countries. ${ }^{26}$

A case of which I have intimate knowledge may show us the fate of an inventor who refused to join any kind of combination. I ask the pardon of the reader while I tell the story of my father. In Igor he applied for a patent protecting a process to use tung oil, imported from China, for insulating varnishes. This patent application was the first application for a polymerization patent. The varnish industry realized immediately the tremendous importance of this patent and of the process for which protection was sought. The Association of the Varnish Industry, a corporation registered in Germany, together with importers and other manufacturers, filed objections against the patent. It went up through the divisions of the Patent Office. The inventor risked his whole property, and the

${ }^{26}$ Address in honor of Sir William Perkins in London, July 24, I906, at 54 (Perkins Jubilee ed. I906). 
property of friends as well, in an attempt to obtain a patent grant. The association applied to the Reichsgericht but was unsuccessful. Later each member of the association filed a new suit in the first instance in the Patent Office, and again the case went through the courts, until the Reichsgericht gave the patent to the inventor-just when the seventeen years were over. The significance of the patent is shown by the fact that in 1903 the United States imported 2,998,000 pounds of tung oil, whereas in the following year, 9,I6I,000 pounds were imported. This increase was a direct result of the invention. ${ }^{27}$ The inventor became a chemist of very high reputation, but other people became rich.

These instances show how between 1877 and the outbreak of the war in I9I4 the German patent law was perverted. It became a means of monopoly control; private inventors who tried to use patents for their protection without giving in to the demands of the monopoly powers were defeated by the patent procedure. ${ }^{28}$

The development of substantive patent law went in the same direction. Herman Isay set forth a new doctrine of patent protection, namely, that the protection should not be limited to the text of the patent itself but should cover any new process opened by the patent. ${ }^{29}$ For practical purposes Isay's distinction between the scope of the patent itself and the scope of the patent protection means that knowledge of the patent itself is not sufficient to establish whether or not a certain process is protected by the patent, or what shall be considered as new. ${ }^{30}$

A principle of even more general application than in the patent field, namely, the principle of individual freedom to do business, as provided in the Gewerbeordnung of I900,35 had the same fate. The process of perverting the free economy was favored in a very fateful way by a shift in public opinion toward disfavor of free competition. The victory of the opinion considering free competition as a chaotic economy deprived the institution of competition of its character as a regulating factor in the economy. The conception of competition was defined by the courts in a thoroughly anarchistic way. It is really astonishing how easily economic competition and institutions hostile to dictatorship were sacrificed to the

${ }^{27}$ I Mattiello, Protective and Decorative Coatings I6 (I94I).

${ }^{28}$ The leading lawyer of big business in Germany, Herman Isay, was of another opinion. He called the patent policy a weapon of small industry. See Isay, Die Funktion der Patente im Wirtschaftskampf (1927).

29 Isay, Patentgesetz I9I (I930).

30 Besso, Grenzen des Erfindungsschutz $\mathrm{I}_{3} \mathrm{I}_{4}$ (1934).

${ }^{3 x}$ Statute of June 30, I900, Reichsgesetzblatt at 87 I. 
private monopolistic trend. The liberal institution of competition itself was even handed over to the monopolistic powers who used it as an instrument in the destruction of free competition.

The result of this development was that the principle of free competition was transformed into the opposite principle of senseless fighting between economic powers. Everything was permitted, even though it was outside the pale of business and inconsistent with law or good morals. During the period between I879 and I9I4 the whole development was based on the decision of the government and the Reichstag to enact a high tariff statute and could have been changed by the government in the same way. ${ }^{32}$ This action was at least a remainder to industry that the government had the power to act. Patents could be influenced by the government in the following ways: I) by compulsory license;33 2 ) by governmental use of patents according to administrative decisions; ${ }^{34}$ and 3 ) by refusing compensation for use in the interest of the government. ${ }^{35}$ Here is one of the essential differences between the conditions before and those after the first World War.

Another element, however, in favor of the government was its bureaucratic and military control of all that was going on in the country. The significance of the bureaucratic and military power of the German administrative machinery and of the social preeminence of the people connected with it, before IgI4, cannot be overestimated. Although the groups in social life which were later to destroy the government already

${ }^{32}$ An amendment to the tariff statute was proposed by a member of the Reichstag, but was rejected. This proposal provided that import duties would be abolished "if syndicates, trusts, cartels, conventions, etc., should demand unreasonable prices in Germany." Ausschuss zur Untersuchung der Erzeugungs- und Absatzbedingungen der deutschen Wirtschaft. Verhandlungen und Berichte. 3. Arbeitsgruppe, Wandlungen in den Rechtsformen der wirtschaftlichen Organizationsformen, t. 4. Kartellpolitik 2 (I930).

${ }_{33}$ The amendment to the patent statute of June 6, x9rr, Reichsgesetzblatt 243 , provided, "If the owner of a patent refuses to permit someone else to use his invention in spite of the offer of a reasonable fee and guarantee for the payment of the fee, the other person can be granted the permission to use the invention, if such grant is considered necessary in the public interest [compulsory license] and the permission may be granted with certain limitations or may be granted under certain conditions."

34 Ibid., at $\S 5, \uparrow 2$ provided, "The patent has no effect to the extent that the invention shall be used for the Army, Navy or in other ways in the public interest, in accordance with the determination of the government. However, the patent owner is entitled to ask for reasonable compensation from the Reich or the state which applied in its interest for the limitation of the patent protection. If no understanding between the patent owner and the government can be reached the court may determine compensation."

${ }_{35}$ The court had no jurisdiction to decide about a case against the government for infringement of a patent if the patent had been used to accomplish strictly governmental aims. Isay, Patentgesetz $\pi_{4}$, n. 7 I (1930). 
were in the making, society did not develop the state of "pluralism" in which private groups subordinate the national policy to their own interests and ends. ${ }^{36}$

How did the world react to this development in Germany? Very slowly, just as it did after the events of 1933 . The first reactions were in patent law. The English statute of $1907^{37}$ provided for the loss of a British patent for non-use in the British Isles. The result of this measure was an increasing influence of German industry in the internal economy of the British Empire itself. The two large dyestuff groups (Agfa-Bayer and BadischeCassella) acquired large terrains in England "which [are] fit to serve for plants for the dyestuff industry and even for the manufacture of all inorganic intermediaries or tar distillations." 38 Duisberg seemed not too much concerned about the reaction to the German expansion. He wrote:

We studied the conditions in all directions and we learned surprisingly that coal is much cheaper in England than in our country, that the wages for workers are much lower than in our country, that the taxes to be paid and the other governmental burdens are much lower than in our country. The only thing that is more expensive is the freight, which is not important at all. 39

${ }^{36}$ The conception of "pluralism" was used first by Carl Schmidt, the analyst of Germany's constitutional law-who is highly gifted with intelligence by lacking in character, and who served all governments which Germany had after Igr4 as a capable adviser.

37 Patents and Designs Act, 7 Edw. VII, c. 29, $\$ \S 24-27$ (Ig07), provided in effect that the patentee shall be deemed to have been abused his granted rights in the following circumstances: (a) If the patented invention be one capable of being worked in the United Kingdom, and is not being worked within the United Kingdom on a commercial scale and no satisfactory reason can be given for such non-working. (b) If the working of the invention within the United Kingdom on a commercial scale is being prevented or hindered by the importation from abroad of the patented article by the patentee or person claiming under him or by persons directly or indirectly purchasing from him or by other persons against whom the patentee is not taking, or has not taken, any proceedings for infringement. (c) If the demand for the patented article in the United Kingdom is not being met to an adequate extent or on reasonable terms. (d) If by reason of the refusal of the patentee to grant a license or licenses upon reasonable terms, the trade or industry of the United Kingdom or the trade of any persons or class of persons trading in the United Kingdom or the establishment of any new trade or industry in the United Kingdom is prejudiced and it is in the public interest that a license or licenses should be granted. (e) If any trade or industry in the United Kingdom or any person or class of persons engaged therein is unfairly prejudiced by the conditions required by the patentee, whether before or after the passing of this act, for the purchase, hire, license or use of the patented article or to the using or working of the patented process.

${ }^{8}$ Duisberg, Gesellschaft deutscher Chemiker I962 et seq. (I908).

39 Ibid. It is interesting that Duisberg immediately used this opportunity to threaten his political adversaries by saying, "Our high-tempered persons in the political feld should be warned to be careful. For the time being we only intend to use our patents in England, which is at the present time important for us, and thus England will not gain a stronger position in the chemical field. All that the English newspapers wrote about this is exaggeration. We 
The United States did not follow the English example. It did just the opposite, signing a treaty with Germany on February 23, I909, providing:

Art. I. The provisions of the laws applicable, now existing or hereafter to be enacted of either of the Contracting Parties, under which the nonworking of the patent, working pattern (Gebrauchsmuster), design or model carries the invalidation or some other restriction of the right, shall only be applied to the patents, work patterns (Gebrauchsmuster), designs or models enjoyed by the citizens of the other Contracting Party within the limits of the restrictions imposed by the said Party upon its own citizens. The working of a patent, working pattern (Gebrauchsmuster), design or model in the territory of one of the Contracting Parties shall be considered as equivalent to its working in the territory of the other Party.40

At this time the United States was in its developmental stage. The desire to get the most modern products the world produced was so great that even the highest tariffs introduced by Congress did not prevent those who imported German goods from bringing them into the country. The United States was not too seriously interested in the international market and in competing with English or German firms. Furthermore, the American firms found much larger profits in using the natural resources of their country than they could ever hope to get out of the relatively small profits from production which required experience and expensive, risky research with strict organization. ${ }^{4 x}$

An interesting attempt to resist the abuse of the patent system was made by Switzerland, which refused to give any chemical patents up to I906. The German chemical industry was very much excited about this fact and urged the German government to include a special provision in the commercial treaty between Germany and Switzerland requiring that Switzerland grant such patents. Interesting are the figures mentioned by the speaker for German industry. He alleged that Switzerland established six or seven chemical plants "which manufacture in my opinion about 20 to 25 million francs of dyestuffs. Switzerland needs about 5

came with two chemists and 50 workers. What does that mean as compared with 500 chemists and 18,000 workers which we employ here? But let us be clear about that. The beginning is made and who knows what comes. England may enact a statute providing high tariffs. Under such circumstances we should be careful and not go too far in our social legislation in order to make more inconvenient for us the conditions of production."

40 Papers Relating to the Foreign Relations of the United States 224 (I909).

4 Duisberg, The Influence of Liebig on the German Chemical Industry (IgO4), reprinted in Duisberg, Abhandlungen, Vortraege und Reden (I923). 
million francs. About I 5 million francs dyestuff are exported out of Switzerland. The export of dyestuffs from Switzerland to the United States amounts to about 5 million tons-even from Switzerland to Germany dyestuffs are imported [in the amount of 3 million francs]." ${ }_{42}$

The second reaction was the increase of import duties. Here the United States led, while England did not dare to leave its traditional policy of free trade because of the extremely difficult Empire problems which a high tariff policy was sure to raise. As high as the tariffs enacted by the American legislators may have been, the special provisions avoided any serious threat to the German policy as described above. Duisberg pointed out that the tariff policy of the United States did not affect the import of intermediary products which could be transformed in the United States by German owned plants. ${ }^{43}$ Furthermore he claimed that the import duty in pharmaceuticals amounted to almost Ioo per cent without interfering with the German export policy. ${ }^{44}$ He indicated that he did not expect a change of the tariff, but he clearly anticipated the day in which that might happen under other circumstances.

The third reaction was to paralyze the German cartels by cooperating with them through international cartels. Cooperation was necessarily connected with the abandonment of the policy of dumping. This development of international cartels was still at an early stage and did not go too far before I9I4. ${ }^{45}$ For example, German industry could agree to join the chloride of magnesium cartel and the bromine agreement without giving

${ }^{42}$ Protokoll des Kongresses fuer gewerbliches Eigentum in Hamburg 143 et seq. (1902).

43 Duisberg's Memorandum, submitted to the members of the boards of all dyestuff firms in Germany in I904.

44 Duisberg, Lebenserinnerungen 88 (1933).

45 Interesting instances are the chloride of magnesium cartel and the bromine agreement. Under the cartel members had established quotas, which were reduced if new members came in. Production and prices were fixed. Even though Great Britain produced this item most of the German production was used there. Therefore, in order to secure this market, agreements incorporating similar provisions were made with English producers. In the brome agreement all brome derivatives were sold to an international cartel to which English, German, French, and Italian firms belonged. The management of this cartel was entrusted to the Vereinigten Chemischen Fabriken auf Aktien vorm. E. Schering, predecessor to Schering-Kahlbaum in Berlin, the parent corporation of Schering, Inc., of New Jersey. These two international cartels represent two different types of international cartel organizations, since in the first cartel the production and prices of two countries are regulated by agreements between two cartels while in the second form only one cartel existed whose sales agency distributed orders and profits. Both forms of the cartel are equally important for the purpose of avoiding dumping. 
up its general policy, because not the slightest difficulty was encountered in selling its production in these two fields; hence the expensive dumping process was unnecessary from the German point of view. In spite of the general interest which these early international cartels have, they cannot be considered an efficient defense against all industrial oppression.

The international patent cartels in existence before IgI4 had the aim rather of giving foreign corporations, which controlled an invention, access to Germany than of giving German firms access to markets abroad. In 1883 in the electric light bulb industry, the system of exchange of information and patents developed which finally led to the Patent-Interessen-Gemeinschaft on March I5, I9II. This association, of which the General Electric Company was a member, guaranteed each member a free license under all the patents of all other members and the joint protection of these patents against any attack. Outsiders could get a license only if the association decided unanimously to grant the license. Since in this field the American development preceded the German, we are more interested in the American inventions than in the German. A similar case could be found relating to radio patents. The Marconi Wireless \& Telegraph Co., Ltd., an English corporation organized in I897, controlled the patents relating to the use of radio on ships. Before $x$ gा $x$ Telefunken could not even prevent Marconi from controlling the wireless on German ships. Telefunken's research produced new inventions in other related fields however, while Marconi became interested in participating in the German market in fields other than wireless telegraph. Therefore Telefunken and Marconi agreed to exchange patents; this agreement was the basis for a very efficient world distribution system. Telefunken became a partner of Marconi in the Belgian Compagnie de Télégraphie Sans Fil, and a worldwide distribution of markets was in the stage of preparation when the first world war broke the contract for the time being..$^{46}$

All in all the resistance of the outside world against the new German cartel and tariff system grew from year to year. At the same time German industry developed more and more. The clash between Germany and other nations became unavoidable. The German fortress, from which goods could be sold cheaper throughout the world, became increasingly

- an encircled fortress which in the end could save its existence only by bursting its encirclement through aggressive use of its pent-up resources. The more immediate the danger of war, the greater became the significance

${ }^{46}$ Von Bronk, Telefunken Patente, in 25 Jahre Telefunken (I928). 
of the government as the best customer of industry. In IgI4 Germany entered the war as a nation which appeared to be unified to a degree never before seen, but as a matter of fact the government was only the most powerful group within a number of groups which existed inside the nation, among them the cartels and the unions. The question was, how long could it remain the most powerful group, especially since the outbreak of the war deprived the government of its most effective method of control, through the tariff policy. How long could the full outbreak of the domestic crisis, the development of "pluralism," be avoided?

In the very beginning of the war the government as the largest customer could, directly or indirectly, dictate conditions. But industry realized more and more that the government had no choice other than to give in to the demands of the cartel and, to a certain degree, to the demands of the unions. Even if German economy had not made any real preparation for the war, ${ }^{47}$ Rathenau and Koeth, organizers of the German war economy, nonetheless found ready the entire equipment they needed, namely, an organized economy. which could easily produce a maximum of certain goods, restrict production of other goods, and replace some scarce products with newly invented substitutes. The whole machinery of the cartels, built up by private groups for the purpose of cornering markets and distributing profits which had been dependent on governmental policy, became for the moment the tool of the government's war policy. The cartels were made the basis of all the so-called "war corporations." When these corporations were established, it was intended not only to provide a supply of raw materials by seizure but also to purchase goods in the domestic market and to import other goods. All persons involved were accustomed to see products, orders, and profits distributed and divided. ${ }^{8}$ Von Beckerath, who had a very good chance to observe the activities of the cartels himself, made the statement that this "war service" was a very profitable business for the cartels and the industrialists behind them. ${ }^{49}$ The longer the war went on, the more the government had to learn that it was absolutely dependent on the fullest cooperation of industry, which was expected not only to produce but also to substitute its processed goods for natural products to a very large extent. This program of substitution formed the basis of the similar development which has become of greatest importance in the present war. The major problems

47 Heymann, Die Rechtsformen der militaerischen Kriegswirtschaft (I92I).

${ }^{8}$ Ibid., at ${ }_{3} 37$.

49 Von Beckerath, Der moderne Industrialismus 257 (I935). 


\section{attacked were synthetizing rubber, ${ }^{50}$ nitre and nitrogen,$^{5 x}$ and the develop- ment of metallurgical alloys. ${ }^{52}$}

so "This product was produced from the derivatives of coal tar. Isoprene is a carbohydrate. This could be transformed into rubber by polymerization. This rubber was identical with the natural rubber, as the experiments of Dr. Harries proved. We were successful in transforming the higher homolog of isoprene, methyl isoprene or dimethylbutadiene, and the lower homolog of isoprene, butadiene, into two new forms of rubber. These two forms were elastic and similar to natural rubber, but different in several respects.

"Although we could not hope to manufacture isoprene as cheaply as the product obtained from natural rubber, we nonetheless began to manufacture methyl rubber, which was rich in carbohydrate, since it was much easier to produce and had a higher degree of homolog. This was done at a time when natural rubber was very expensive (20 RM per kilo). Therefore it was not difficult to put the artificial product on the market. [When the price of rubber fell the artificial product no longer went to market.]

"On the other hand, the experiments in the research laboratory were continued without interruption, to improve the quality of the product and to decrease the costs of manufacture. We tried to use not only methyl rubber but also the two other synthetic forms of rubber. New experiments were made, together with some rubber companies in our neighborhood, especially with Clouth in Köln. We tried to use the different synthetic rubber forms for all purposes." Duisberg, Lebenserinnerungen ror et seq. (r933).

5x "A great problem solved by us was the problem of synthetic nitrogen. Before the war Badische Anilin manufactured ammonia out of nitrogen in accordance with the Haber and Bosch process. When the war broke out a plant was just being established for the production of 150,000 tons of ammonia annually. In the meantime Ludwigshaven began to double its plant.

"Since it was necessary to give our farmers as much nitrogen as possible, the production of calcium nitrogen in the plant in the neighborhood of Köln was raised to 120,000 tons. We had the Bavarian plant in Trostberg which produced 25,000 tons. Two new governmental plants were established in the province of Sachsen and in Upper Silesia. The Reich made a contract with the Badische Anilin to establish a plant with a productive capacity of 150,000 to $180, \infty 0$ tons of ammonia sulphate. This plant was established in the neighborhood of Merseburg and began work in Igr 7. This plant was called Leunawerk and was organized by the Badische Anilin. Germany became self-sufficient in nitrogen before the war. . . . . Because of the needs of the war, German industry became independent in another field, the supply of sulphur." Ibid., at II 2 et seq.

s2 ". . . . manganese is not only important as a means of alloying in the preparation of steel, but it is also important for use as a means of deoxidation. Many experiments were made to save manganese as an alloying material and to substitute it as a deoxidation means. Very soon we learned to save manganese. Calcium carbide was discovered as a full substitute for manganese in connection with deoxidation, and thereby we cheapened the manufacture of steel by 8 pfennig per ton. The large increase of the price for nickel and chrome made it possible to utilize mines in Germany which could not be utilized earlier. The Stahlwerke Richard Lingenberg in Remscheid introduced steel which was poor in nickel for these purposes. With the help of electro-steel ovens wolfram would be substituted for molybdenum. The best mine for molybdenum oxide lead was found in the neighborhood of Garmisch in Bavaria.

"To make us independent of foreign countries in the field of aluminum, three plants were established in Germany at places at which electrical power was cheap and ample. These plants supplied the entire German needs of aluminum. We used in the beginning Hungarian bauxite as raw material, and later German clay.

"In Bitterfeld a new plant for the manufacture of a new metal, just discovered, was estab- 
The government had the power not only to grant compulsory licenses to firms interested in the inventions which were patented as a result of this research, but also to prevent the publication of any patent which might be important for war materials. The government did not use this power in many cases, especially insofar as big industries were concerned. No source is available which gives information on this point but I know of only one case in which the government prevented the publication of a patent. In this case the inventor and the applicant were relatively weak. ${ }^{53}$

The two most efficient uses the government made of its economic influence were the following: I) The government itself became a manufacturer, especially of aluminum. Research findings prepared by the Metallgesellschaft and Griesheim Elektron were utilized for the establishment of a large government aluminum plant, which still remains under the control of the government. ${ }^{54}$ 2) The establishment of compulsory cartels and the compulsory merger or closing of plants was brought about. Insofar as the industrialists could not agree in the organization of cartels and the government accordingly could not rely upon such cartels in certain fields, the government established compulsory cartels. ${ }^{55}$

The practical history of the compulsory associations as established during the war shows, however, that it was not so much the government command which regulated these compulsory cartels as it seemed. After the cartels were once established, it could be seen quickly that the big industrialists inside the compulsory cartels had a more or less absolute leadership. Very often, if not in most cases, the suspicion arose that the cartels were made compulsory only on the request of the big fellows because of the refusal of one or another of the small industrialists to join.

There is no doubt that at the beginning of the war the government had a very strong psychological position which was not used at all. In spite of their conservatism the Prussian militarists were very much influenced by

lished. This metal, called 'Electryon,' was made out of magnesium alloyed with manganese and aluminum. This metal was manufactured out of a by-product of phosphate salt fabrication of chlorine magnesium. Electryon was a very good substitute for aluminum." Ibid., at I25 et seq.

53 The patent involved dealt with the substitution of fats and oils in printing.

54 "A. new big plant for the production of aluminum will be completed very soon. This plant will not use foreign bauxite but German clay, so that we will now be independent from foreign markets in the field of acetic acid and also in the sale of aluminum, and even in peace will be able to substitute large amounts of imported copper for domestic aluminum." Duisberg, 24 Z. Elektrochemie 369 (Igr8), 38 J. Soc. Chem. Ind. I88A (I9I9).

ss The idea of compulsory associations was not unknown in the German law. Such compulsory organizations were known for quite a long time, as for instance, fishery associations. 
the liberal economic theory that government should not interfere in business. The government lost its chance very soon. From month to month a change in public opinion with regard to social classification could be seen. Public opinion, even in the groups of militarists themselves, considered a Wirtschaftsfuehrer as the type of person replacing the generals and high officials in the social classification. The ideology of the government had nothing to offer against the demands of technologists, industrialists, and financiers. Walther Rathenau made the only attempt to give an ideological basis to the fact that industry and business had to devote themselves to the aim of the government in time of war. Rathenau established for the first time the character of an enterprise as a kind of public good, subject to the commands of the government, which alone can be responsible to the national state. ${ }^{56}$

The development after the war was over can be understood more easily if we have in mind the following facts:

I. German industry lost its foreign subsidiaries, foreign patents, and foreign property.

2. Other countries could freely establish high tariffs while the German government lost its power to regulate tariff legislation independently.

3. German industry was confronted with a large number of new European states, such as Poland, Czechoslovakia, and Jugoslavia, which all had new tariff borders and tried to become as nearly self-sufficient as possible.

4. German industry had to import raw materials which, up to IgI8, it had in its own territory, especially zinc, which now had to be imported to a large extent from Upper Silesia, which was under Polish jurisdiction. ${ }^{57}$

5. German industry, on the other hand, had a very much greater capacity than it had before the outbreak of the war, because during the war new plants were built, technical processes developed, and equipment installed without any consideration for the economic future. The same happened in other countries, which up to the war sent their raw materials to Germany to have them transformed into finished products.

6. The government itself lost not only its tariff power but also its social standing. The industrial class prevailed in the social structure of the nation.

7. The government had to rely upon industry in connection with the performance of many provisions of the peace treaty, for instance, that

${ }^{6}$ Rathenau, Von kommenden Dingen 145 (I918).

57 Bergmann, Der Weg der Reparationen II2 (I926). 
requiring the export of a certain amount of coal dyestuffs to the victorious countries, which provision could only be performed by the dyestuff industry.

8. The government had to rely upon industry in the problem of demobilization and of transferring the returning army men to jobs in industry.

9. The government lost its position as the largest customer for armament purposes and could not reestablish this position.

Two outstanding events made the situation much worse. First, there was inflation. While the government could not cancel its foreign debt and while its domestic debt reappeared almost immediately, especially the debt connected with the peace treaty, industry undertook to cancel its own debt by the inflation policy. Second, the threat which existed during the whole inflationary period that a merchant might lose his entire capital by selling his products for paper marks without regard to the replacement costs, became the basis for the cartel agreements between producers, wholesalers, and retailers, which will be discussed later.

During the inflation the industrial merger movement developed very fast. The statistics relating to corporations in the time of inflation do not give us a true picture, because business organizations were established practically without foundation. The increasing number of corporations does not clearly reveal the fact that during the inflation period the control of the entire German corporation capital began to be confined to an ever decreasing number of people. In this connection it may be stated that according to the statistics of I940 the management of I7O German corporations controlled $5^{6}$ per cent of the entire German business capital..$^{8}$

Inflation's worst immediate effect on the German economy was that industry, which already had a capacity much exceeding any regular German market, increased its technical capacity to a larger extent. Then came a period of "rationalization" and again German capacity grew even further, with the help of American loans.

After this development the crisis began, for there was practically no idea what to do with this tremendous industrial power. Pre-war history, the development during the war, and this last development established a complete domination of German economic life by the industries which used these devices: the monopolization of products, the patent monopoly power, and predominant capital power. In all fields in which any group

${ }^{8}$ Frankfurter Zeitung (Nov. 16, 1940). 
could exercise one of these powers, the industrialists, after they completed their own cartels, informed the wholesalers that they would only be supplied if they became members of the wholesalers' cartel, and the wholesalers informed the retailers that they would only be supplied under the same conditions as those under which the industry supplied them. A typical example of the conditions in a field in which the production was monopolized is the Association of German Screw and Nut Producers. This association made an agreement with the Association of Screw Wholesalers. The by-laws of the association of wholesalers read as follows: "The purpose of this association is the regulation and improvement of the German screw business, especially the fixing of prices in the screw trade and the performance of eventual contracts to be made with the Association of German Screw and Nut Producers, Düsseldorf." No member of the producers' association (and as early as I929 there were no independent producers) could supply any wholesaler or any one else who was not a member of the trade association. The agreement between the two associations regulated the kind of products to be sold and the price and conditions of delivery, not only between manufacturers and wholesalers but also between wholesalers and retailers or any other kind of customers.

Immediately after the inflation there was practically no field in the coal, iron, steel, or metal industries in which the producer had not an absolute control over the sale of his products reaching from his plant to the last consumer. It would not serve our purpose to describe many instances of these contracts. Nevertheless brief reference may be made to the decisions of the cartel court where typical situations in which businessmen resorted to this court are described. ${ }^{59}$

A case typical of the second situation, the monopolization based on patent power, is the case of Telefunken. Telefunken controlled the Fleming patent which protected the cathode detector tube and the electrode tube, and patents relating to the circuit. ${ }^{60}$ That gave Telefunken, up to I94I a subsidiary of Siemens \& Halske and A.E.G., an absolute control over the radio industry, wireless industry, and all enterprises manufacturing related medical equipment. ${ }^{6 x}$ In the field of radio the Government in-

s9 The cartel court is organized in accordance with the provisions of the cartel decree of 1923. The cartel court was abolished in I940 and its tasks were entrusted to the Reichswirtschaftsgericht. The jurisdiction of the cartel court or of the Reichswirtschaftsgericht exists, for instance, in cases in which a member of a cartel alleges that the continuance of his membership is inconsistent with public interest and cannot be expected.

60 Von Bronk, Telefunken Patente, in 25 Jahre Telefunken (I928).

6x Equipment to examine heart activity and auditory disturbances is an example. 
duced Telefunken to give a certain number of licenses. ${ }^{62}$ From the very beginning, however, the grant of any license was made dependent on the joining of a cartel. Whereas the full effect of this system did not become clear before Hitler came into power, the appropriation of the associations of the radio industry and the radio trade by the National Socialist government amounted to a subordination of an existing commercial system under the political command of the party. The regulation of the market was accomplished before Hitler, as a market regulation by patent, effective from the manufacturer to the last consumer. That could be accomplished although the patent referred only to a relatively small part of the product sold. The National Socialist government was so much concerned when one of the important Telefunken patents came to a natural end that the government by decree provided that the patent "market regulation" should continue. ${ }^{63}$

Discussions of the German monopoly situation have been confined too often to I. G. Farben. ${ }^{64}$ This combine may be classified between the group monopolizing by patents and that monopolizing by capital power. More and more the chemical industry began to apply for patents on practically everything. The research laboratories of the few remaining chemical works, connected among themselves by cartel and working agreements, systematically studied entire fields and closed them by a large number of patents. That was true in the development of plastics (the participants were I. G. Farben and Rohm \& Haas) and in most pharmaceuticals (the three groups of enterprises participating were I. G. Farben; Merck, Boehringer and Knoll, connected by a joint sales agency and an agreement relating to the exchange of information, etc.; and Schering-Kahlbaum A. G.). Each publication in any chemical review or each patent application of any applicant in any country was given to the staff of the research laboratory to find anything that could be patented, no matter if the patent was a patent of evasion or supplement or protection against other inventors. ${ }^{65}$

${ }^{62}$ As far as other uses of the tubes were concerned, it was extremely difficult to get any kind of license from Telefunken. I myself tried, on behalf of a client who had a very excellent reputation as a scientist, to get a compulsory license for the manufacturing of equipment for testing human hearing. The only success was that Telefunken itself brought the article on the market.

${ }^{6}$ Kartell Rundschau 4I2 (I939).

${ }^{64}$ Some people may be inclined to believe that I. G. Farben is the only case.

${ }_{65}$ The terms patents of evasion, supplement, and protection are technical. I understand these terms as follows: I) A patent of evasion is a patent accomplishing the same result as a previous patent of another patentee without infringing it. This is especially so if the new patent is not based on any new theory and does not constitute any economic improvement. 2) A patent designated as a supplement patent is one whose only aim is to secure protection 
But in fields in which the patent situation had theoretically permitted competition, the factual power of the capital investment made such competition impossible. The capital required to build up efficient plants in the field of the heavy industries and the chemical industry, as well as in the machine and metal industry, became so tremendous that only very rich groups could attempt to enter any of these fields. As soon as a plant was completed, as for instance the nitrogen plant in Leuna or the plant of the Vereinigte Aluminumwerke in Lauta, a competitive plant would have been not only a disaster for the new entrepreneur but also for the old entrepreneur and for the public. Therefore, no bank would finance such an enterprise. The Vereinigte Aluminumwerke obtained a patent relating to the manufacture of aluminum out of clay in Igrg. If it had tried to use this patent its just completed plant would have lost its value; therefore, the Vereinigte Aluminumwerke gave a license to its Italian subsidiary, but did not itself use this patent until a number of years later. ${ }^{66}$

So we learn that the government was confronted with the fact that the entire production and market conditions were regulated by the management of a number of corporations which from year to year either decreased or became dejpendent on each other. To say that the government had a domestic policy when production and markets were regulated by monopoly powers, and wages and salaries by labor unions and employers, is to misstate the fact. Moreover, industry was confronted with a new international problem, which Hitler later characterized by the statement, "Export or die." The earlier situation of German offensive and foreign reaction to it was now reversed: the outside world, including the new European states, acted first by enacting high tariffs, by depriving Germany of her tariff power, by licensing systems for imports, for foreign corporations doing business, and for their establishment of local subsidiaries, by seizure of patents and trademarks.

None of the devices used by German industry before the last war could help. The only governmental measure or policy which helped was the agreement between Germany and Russia relating to the financing of German goods to Russia. German industry did not have any chance other than I) to find loopholes in the exclusionary system of the world for whatever reasons these loopholes might exist; or 2) to find help from "within"

for a previously patented process beyond the seventeen year protection period provided by the patent statute. This is accomplished by patenting other aspects of the old invention. 3) A patent of protection is one which blocks the way to patents of evasion or to any real technical progress because it secures the investment of the owner of another patent.

${ }^{66}$ Marcus, Die grossen Chemiekonzerne (I929). 
the outside world. Examples of these two techniques may be found in the chemical industry.

America excluded German dyestuffs and chemicals after peace was reestablished and included in the Tariff Act of $1922^{67}$ the following provision:

If there is no similar competitive article manufactured or produced in the United States then the ad valorem rate shall be based upon the United States value as defined in subdivision (d) of Sec. 402, Title IV. For the purposes of this paragraph any coal-tar product provided for in this Act shall be considered similar to or competitive with any imported coal-tar product which accomplishes results substantially equal to those accomplished by the domestic product when used in substantially the same manner. . . . .

If there is any competitive article manufactured or produced in the United States the import duty is much higher. The German industry learned to use this provision for its own benefit in two ways:

I. Nitrogen. In I930 Mr. Bueb, the manager of the nitrogen plant of I. G. Farben, made the claim before a committee of the German Reichstag investigating the structure of the German economy that nitrogen had not been produced in the United States in spite of the seizure of the patent. ${ }^{68}$ The often alleged reason that it could not be produced during the war was that the patents did not describe the process sufficiently. This was verified by Duisberg who later reported that the military control commission of the Allies demanded at the end of the war not only the processes used for production of powder, explosives, and gas but also the processes for production of raw materials such as nitric acid, ammonia, and sulphuric acid, which are the basis of every chemical plant. Much of this had nothing to do with explosives and war materials; the demands came only because of a desire for economic profit. ${ }^{69}$ A list of the import duties to be paid for nitrogen manufactured by Leuna (I. G. Farben) in the different countries was available. ${ }^{70}$ This list states that imports into the United States are free, under position 1583 , in accordance with Paragraphs 27 and 28 of the Tariff Act of 1922 as quoted above. So one loop-hole was found to bring nitrogen into the United States. After I923 the German processes were improved to a very large extent and new patents in this field were taken out. Imports into this country were entrusted to the Synthetic

${ }^{67} 4^{2}$ Stat. 862 ( $x_{922)}$.

${ }^{68}$ Ausschuss zur Untersuchung der Erzeugungs- und Absatzbedingungen der deutschen Wirtschaft. Verhandlungen und Berichte. 3 Die deutsche chemische Industrie I $5^{\circ}$ ( $193^{\circ}$ ).

${ }^{69}$ Duisberg, Lebenserinnerungen $\mathrm{r}_{34}$ (I933).

70 Ausschuss zur Untersuchung der Erzeugungs- und Absatzbedingungen der deutschen Wirtschaft. Verhandlungen und Berichte. 3 Die deutsche chemische Industrie I88 (r930). 
Nitrogen Corporation which was under formal control of an American friendly to I. G. Farben interests.

2. Dyestuffs. The Alien Property Custodian of the last war was especially active in regard to dyestuff corporations. He repeatedly stated that the German dyestuff monopoly was of extreme danger to the safety of the United States. Therefore when he was asked in a Senate Committee investigation whether the German dyestuff firms should be excluded forever, he answered in the affirmative. In I9r9 he sold $55^{8}$ patents and one trademark belonging to the Elberfelder Farben Fabriken Bayer and Co. to Sterling Products Co. ${ }^{7 x}$ The dyestuff patents of other firms were sold to Chemical Foundation, Inc. But these two groups of patents came back under the control, or at least strong influence, of the predecessors of I. G. Farben. The dyestuff patents sold to Sterling were not of immediate interest to that firm which was producing only pharmaceuticals. Sterling Products sold its dyestuff interests to Grasseli Chemical Co. In I924 the Grasseli Chemical Co. came to an agreement with Elberfelder Farben Fabriken Bayer and Co. and another predecessor firm of the I. G. Farben, the Farbwerke vorm. Meister, Lucius and Bruening. In accordance with this understanding the Grasseli Chemical Co. assigned all dyestuff patents to a new corporation, the Grasseli Dyestuff Corp., to which Bayer assigned its present and future United States patents and trademarks relating to the manufacture of dyestuffs granted or applied for after the end of the war. Bayer acquired an interest of 50 per cent in the patents while Grasseli Chemical kept 50 per cent. Later the Hoechster Farbwerke acquired a sub-interest under Bayer. In 1925 the participation in Grasseli Dyestuff was changed when Grasseli Chemical reduced its participation to 35 per cent, and Bayer reduced its participation to 30 per cent, while the balance was assigned to $\mathrm{H}$. A. Metz as trustee for Hoechster Farbwerke and to other predecessor firms of I. G. Farben. In the same year this company became the exclusive selling agent in the United States for all dyestuffs of the I. G. Farben firms. Grasseli Chemical changed its name to General Dyestuff Corp. The personnel of this firm was obtained by combining the dyestuff sales personnel of Grasseli Chemical, which was taken over by du Pont, with the dyestuff personnel of the firms of H. A. Metz and Kuttroff Pickardt and Co. General Dyestuff was optioned to I. G. Farben in 1926 , and in $1928 \mathrm{I}$. G. Farben acquired all the shares of this corporation and its name was changed to General Aniline Works.

There was another method by which the German dyestuff corporations returned to the American markets. The Chemical Foundation issued an

${ }^{7 x}$ See Report of Alien Property Custodian, S. Doc. $18 \mathrm{r}, 67$ th Cong. 2d Sess. (rg22). 
import license, after the War Trade Board had given its consent, to Kuttroff Pickardt Co., Synthetic Nitrogen Products Corp., and General Dyestuff Corporation. Kuttroff applied for licenses on certain of the patents of Chemical Foundation, Inc., all of which were granted. These licenses, in conjunction with the devices discussed above, opened the way for renewed importation of important German dyestuffs protected by patents both new and old.

As soon as these devices had accomplished their purpose, the Germanowned subsidiary plant-the General Aniline Works manufacturing products within the United States-had an immediate advantage because products manufactured by any other foreign competitor, for instance, Swiss competitors, were excluded under the above mentioned provision of the American tariff act. Any domestic competition that arose could be excluded by patents newly granted for dyestuffs.

Here then is the basis for one of the most important devices which gave German industry a chance in spite of all exclusionary legislation, inasmuch as these domestic subsidiaries enjoyed all benefits provided for domestic corporations. Any kind of exclusionary legislation passed in addition to that already in existence now worked in favor of the Germancontrolled subsidiary.

In I932 Imperial Chemicals joined the German-Swiss-French cartel; thus the entire front outside of the United States was consolidated. This international cartel controlled within the United States the following subsidiaries in the dyestuff field: General Aniline, Ciba, Inc., Sandoz, Inc., Geigy, Inc., and Cincinnati Chemical Corporation..$^{72}$ Furthermore, it controlled sales agencies and several manufacturing plants in almost every Latin American country of great importance. Although the United States subsidiaries ostensibly did not become members of the cartel, actually they were subject to the active control and direction of the cartel managers. The technique of controlling subsidiaries was implemented by the use of the patent system. Since the cartel firms had patents in every country of the Americas they could exclude the United States subsidiaries from the Latin American market by assigning only the United States patent to the subsidiary. Then, should the subsidiary supply any firm in a country outside the United States without the permission of the owner of the patent in that country, it would violate that patent. This form of international cartel is directed from without against the interest of the United States by means of the subsidiary device and from within by the patent device.

${ }^{72}$ See United States v. Allied Chemical and Dye Corp., to U.S.L. Week 2779 (I942), for indictment of United States members of this cartel. 
There is another kind of international cartel in which the situation is different. In some cases the German position was not strong enough either to prevent the establishment of a plant in the United States, and thereby to use all benefits granted by the United States tariff legislation, or to exclude foreign and American competition by establishing subsidiaries in this country. Then German industrialists had to look for an American enterprise which was interested in those patents, either because it had other patents which could be made much more useful and valuable by exercising the license of the German patents, or which was afraid of the use of these patents in this country as a competitive means against its own products. As a practical matter then the American firm was willing to pay substantial amounts of money either to participate in the German patents or to exclude them or to exchange its own patents for the German patents. In these situations another form of international cartel was established. An interesting instance is the production of electric light bulbs. As was mentioned above, even before the outbreak of the last world war there was an electric light bulb patent association which made possible a complete exchange of all General Electric patents for all patents of other members. This system was resumed as soon as the last world war came to an end. At the end of I924 the entire world electric light bulb production outside the United States was formally cartelized by two agreements: I) the general patent and development agreement and 2) the agreement establishing the Phoebus S. A. (Compagnie Industrielle pour le Développement de l'Eclair A.G.). ${ }^{73}$ Phoebus had to guarantee to a certain extent the distribution of markets, the standardization of products, and restriction of production. The fact that the United States is not a member of this cartel because of the antitrust legislation did not impress the president of the German electric bulb company, Osram G.m.b.H.K.G. ${ }^{74}$ The participation of an American enterprise in a world cartel chiefly through the device of patent exchange became very common. The full consequences of this device did not become clear before Hitler came to power. Its destructive character from the point of view of American security will be discussed later.

The only case in which this device became more like a partnership than like a cartel agreement was the Standard Oil-I.G. Farben case. ${ }^{75}$ Carl

${ }_{73}$ This cartel took the same form mentioned above in connection with the first German cartel, Rheinische Kohlen Syndikat.

74 Meinhardt, Kartellstelle des deutschen Reichsverbands der Industrie 43 (I929).

75 On March 25, 1942, the United States Government and Standard Oil entered into a consent decree invalidating this agreement. United States v. Standard Oil Co. of New Jersey, C.C.H. Trade Reg. Serv. I 52,768 (D.C. N.J. I942). 
Bosch, the president of I. G. Farben, described the purpose of this agreement in the following way:

In the field of the hydrogenation of coal our position is not easy. Therefore we have attempted to find means of cooperating with the big American oil concern, Standard Oil Co. of New Jersey. The field of the petroleum industry is so large and so completely under the control of three large concerns that the consideration of a new production method in a fight against these concerns would have been very difficult.

In the nitrogen field the conditions were quite different. When we began to produce nitrogen we knew that we could produce profitably using the available technical equipment. However, in the field of hydrogenation of coal we knew from the very beginning that it would be years before we could tell whether or not production could be maintained at a price level which would make competition possible. Even if this question could be decided in advance there was the expense of transforming small quantity experiments into production schemes of marketable quantities. The problem of obtaining liquid fuel out of coal is extremely important and its solution is in the national interest. If we had been forced to fight the large American oil companies the financial needs would have exceeded any immediately available funds.

Therefore we believed it best to come to an agreement with the petroleum concerns.

... We made an agreement with Standard Oil by which they might use our process for treating raw oil in the United States. Our joint research work, which was to be the basis of the establishment of large research plants in three refineries of Standard Oil in the United States, proved quite soon that the agreement had to be amended. The business of the Standard Oil is not limited to the United States but covers all the countries of the world. Therefore it proved to be impossible to develop new processes to use and refine oil and its products in the United States and at the same time to restrict the foreign subsidiaries of Standard Oil from using these processes. We learned more and more that we were divulging important discoveries gained in our experimentations with coal and tar hydrogenation by collaborating on the hydrogenation-ofoil problem. The two processes are very closely related. With respect to the coal hydrogenation which is of some importance to Standard Oil, especially in regard to countries which have cheap coal but no natural resources, it will become even more important to Standard Oil when natural oil becomes scarce in the United States. In regard to this process we had no agreement.

To meet this situation and to make sure that our processes would be developed with the greatest possible profit, we decided in I929 to establish a holding company with Standard Oil, the Standard I. G. Company, and to assign to this company the right of using all our patents in the field of hydrogenation in all the world outside of Germany. Standard Oil promised to bring in its patents in the same field. We intended to permit not only Standard Oil and its subsidiaries but the other large oil concerns or other proper firms to use our processes in the fields of oil, coal, and tin hydrogenation. The management of the new company was entrusted to Standard Oil.

We reserved for ourselves, however, the exclusive right to use our new process in Germany and we made a special agreement in regard to the manufacture of gasoline by us for the German market. The conditions of this agreement protect our interests. ${ }^{6}$

${ }^{76}$ Ausschuss zur Untersuchung der Erzeugungs- und Absatzbedingungen der deutschen Wirtschaft. Verhandlungen und Berichte. 3 Die deutsche chemische Industrie 630 (I930). 
Bosch's statement makes it clear that the principal idea is to meet the requirements of the German military effort by producing substitutes, even if more expensive than any available natural raw material. This can only be done if the owners of the natural products were driven from the German market or bribed by high prices not to undersell the substitutes.

- Bosch, an honest friend of peace, became, against his own wishes, the founder of the National Socialist trade policy. He states clearly that he had no chance to develop the hydrogenation plants in the fight against the American petroleum firms selling natural oil, because of the impossibility of competing in price with the natural product. The high price was for Standard Oil an inducement, and for I. G. Farben the condition, of developing new processes in the oil field without which any idea of rearmament was necessarily hopeless.

All forms of international cartel agreements, no matter whether offensive or defensive, deprived the German government of even its international influence. Thus the international policy came to an increasing extent under the control of private groups cooperating with corresponding foreign groups. The list of the members of the committee sent by the government to Russia contains representatives of cartels and monopolies, although that agreement was the only governmental contribution to the solution of economic problems at this time. Perhaps the Russian government preferred to negotiate with them because it realized the allocation of the actual power within Germany.

In I932 the whole process had developed to the point where the German government had lost its power to formulate domest $c$ and foreign policy. The attempts of Chancellors Bruening and Schleicher to restore the state failed. Their only serious attempt to fight can be seen in an emergency decree of the Bruening government decreasing all cartelized and monopolized prices by to per cent. The effect of this decree was frustrated by many policy devices of the "pluralistic" powers. In labor policy the unions followed exactly the same line. They were opposed to any governmental solution of the social situation and were rather in favor of extending their own powers to the greatest extent. For example the Berlin subway strike in 1932 was their answer to the attempt of the government to adapt wages to the depression. This was the condition of the German nation on the eve of Hitler's rise to power. $\S$

$\S$ The development of cartels and patent law under Hitler will be dealt with in a forthcoming issue of the Review. 